\title{
29
}

\section{Women and minority interests in Fiji's alternative electoral system}

\section{Suliana Siwatibau ${ }^{1}$}

\section{The 2006 election}

Candidates from ten different political parties and some 69 independent candidates contested the 2006 national election. Amongst the 336 candidates were some 32 women, three of whom were standing as independents. The large number of parties and independent candidates could be an indication of the people's growing discontent with the policies of the two major parties and of their increasing confidence in political participation.

Table 29.1 shows how the different parties performed. The National Alliance Party (NAP) is of interest as it is a new party contesting elections for the first time. It fielded the third largest number of candidates and also the highest number of women candidates. Both the NAP and the United Peoples Party (UPP) made special efforts to field more women. The UPP, a small party, had 30 per cent women candidates and a gender-balanced winning team. The two major parties - the Soqosoqo Duavata ni Lewenivanua (SDL) and the Fiji Labour Party (FLP) - had poor representation of women candidates at 6 per cent and 12 per cent respectively.

\section{Women's performance}

Of the eight winning women, five stood on SDL tickets, two stood for the FLP and one for UPP. By definition, all gained the required majority of at least 50 
Table 29.1 Summary of party performance, 2006

\begin{tabular}{|c|c|c|c|c|c|c|}
\hline Party & $\begin{array}{l}\text { Total number } \\
\text { of candidates }\end{array}$ & $\begin{array}{l}\text { Number of } \\
\text { women } \\
\text { candidates }\end{array}$ & $\begin{array}{l}\text { Women as } \\
\text { proportion } \\
\text { of total } \\
\text { (per cent) }\end{array}$ & $\begin{array}{l}\text { Seats won } \\
\text { by party }\end{array}$ & $\begin{array}{l}\text { Seats won } \\
\text { by women }\end{array}$ & $\begin{array}{l}\text { Proportion } \\
\text { of women } \\
\text { representatives } \\
\text { (per cent) }\end{array}$ \\
\hline SDL & 79 & 5 & 6 & 36 & 5 & 13.9 \\
\hline FLP & 59 & 7 & 12 & 31 & 2 & 6.5 \\
\hline NAP & 51 & 8 & 16 & - & - & \\
\hline NFP & 44 & 4 & 9 & - & - & \\
\hline NVTLP & 11 & 2 & 18 & - & - & \\
\hline UPP & 10 & 3 & 30 & 2 & 1 & 50.0 \\
\hline PANU & 9 & - & - & - & - & \\
\hline Party of Truth & 2 & - & - & - & - & \\
\hline Justice \& Free & eedom 1 & - & - & - & - & \\
\hline Social Liberty & ty 1 & - & - & - & - & \\
\hline \multicolumn{7}{|l|}{ Independents } \\
\hline Total & 336 & 32 & 9.5 & 71 & 8 & 11.3 \\
\hline
\end{tabular}

Notes: SDL = Soqosoqo Duavata ni Lewenivanua; FLP = Fiji Labour Party; NAPF = National Alliance Party of Fiji NFP = Mational Federation Party; NVTLP = Nationalist Vanua Tako Lavo Party; UPP = United Peoples Party; PANU = Party of National Unity; COIN = Coalition of Independent Nationals Source: The Fiji Times, 19 May 2006.

per cent +1 of the valid votes cast. Of the other women candidates, 17 gained less than 10 per cent of the vote in their various constituencies and seven gained over 10 per cent, with the highest of these garnering 47.5 per cent of the votes in her constituency.

The communal seats were contested by 17 women and the open seats by 15 women. The percentage of candidates who emerged victorious in the Open constituencies was almost double that in the Communal constituencies (Table 29.2).

Did the voters favour women or men? According to at least four women candidates, some women supported them simply because they were women even though they did not specifically campaign solely on gender issues. One of the successful candidates publicly thanked her two main women campaign managers who helped her visit voters door-to-door and for their dedication during the campaign. Another candidate, though unsuccessful, acknowledged 
the support of women's groups in her constituency. This support enabled her to develop a network that has been maintained since the election and is still used to assist and empower women.

\section{Promoting fairer representation}

Despite government rhetoric, women's representation in parliament has remained below the minimum 30 per cent target set. This is due to such reasons as:

- difficulties in adapting very strong traditional cultures and attitudes that see women's status as subordinate to that of men

- continuing male influence over the way women in their families vote

- difficulties of those with little education (often women) comprehending the alternative vote (AV) system

- women being hesitant to nominate for election

- political parties making little concerted effort to encourage women as candidates

- the high cost of election campaigns combined with the relatively poor financial status of women

- the fact that the AV electoral system works against women and minority groups.

While the first two reasons are difficult, long-term problems, the rest would be relatively easy to address given political will. For example, the AV system, which tends to favour large parties over small ones, could be replaced by a system of proportional representation in which smaller parties were represented in parliament in proportion to their popular support; women could be encouraged by government and political parties to stand as candidates; public funding

Table 29.2 Women's performance in communal and open seats

\begin{tabular}{lccc}
\hline Constituency & Number of women candidates & Women winners & Percentage winning \\
Communal & 17 & 3 & 17.6 \\
Open & 15 & 5 & 33.3
\end{tabular}

Source: Analysis of figures extracted from The Fiji Times 19 May 2006. 
could be used to defray the costs of election campaigns; and Fiji could give consideration to a quota system for gender representation in parliament.

Studies of democracies worldwide show the critical role of a country's electoral system in determining the extent of meaningful democracy achieved and in shaping the long-term political landscape. ${ }^{2}$ One of the important features of democracy is its capacity to represent the range of interests and concerns of the populace in decision-making bodies. This requires that small parties representing special interest groups are able to sit in the elected legislative bodies alongside major parties that represent majority interest groups; and that marginalized groups, such as women and youth, are fairly represented.

\section{The smaller parties: the National Alliance Party of Fiji (NAPF) and the National Federation Party (NFP)}

The manifesto of the indigenous Fijian-led NAPF addresses the SDL's blueprint policies by promising to eliminate racial and discriminatory policies and to provide services based on need rather than race. It promises to eliminate corruption in government, and to promote good governance and multiculturalism. It also promises to encourage political parties to set a 50 per cent target for women candidates in elections. The manifesto of the IndoFijian-led NFP promises to enhance genuine multi-ethnic cooperation and power-sharing and to promote respect for the vanua, cultural diversity and ethnic differences. Achieving an ethnic balance in the diplomatic and civil service that would address the current apparent bias towards indigenous Fijians was also an important election promise.

These two parties, with their message of multiculturalism, appealed to small groups within the electorate - and yet neither won a seat, despite having garnered sufficient votes to warrant representation. As mentioned above, meaningful democracy requires such minority parties to be represented in national parliament; an outcome that is less likely to be achieved under Fiji's AV system than it would be under proportional representation (PR).

Table 29.3 shows the percentage of national votes that each party won and the number of seats gained in the 2006 election. It also shows the number of seats each party would have gained had the votes been counted under a full PR system rather than an AV system. The calculations are 
Table 29.3 Party representation in 2006 under AV and PR systems

\begin{tabular}{lrrrrrrrrrrrr}
\hline & SDL & FLP & NAP & NFP & NVTL & UPP & PANU & PT & JF & SL & IND \\
Votes won & & & & & & & & & & & \\
$\quad$ (per cent) & 45.0 & 41.8 & 3.4 & 6.9 & 0.5 & 0.8 & 0.9 & $<0.1$ & $<0.1$ & $<0.1$ & 0.7 \\
Seats under AV & 36 & 31 & - & - & - & 2 & - & - & - & - & 2 \\
Seats under PR & 32 & 30 & 2 & 5 & - & 1 & 1 & - & - & - & -
\end{tabular}

based on the assumption of a PR system that treats the whole country as a single constituency, and no minimum vote threshold for representation in the parliament. In practice, most countries that use the PR system have limited PR systems with sub-national constituencies rather than a single national one. The single national constituency of a full PR system, however, is the closest to fair representation of the electorate; it is used in the Netherlands.

As the election was run on an AV system with single member representation, the comparison in Table 29.3 is only an indication of what would have resulted. Note that under a PR system, three other parties - the NAP, the NFP and the Party of National Unity (PANU) - would have gained seats in parliament. The UPP's share of seats would have been reduced to one.

In Fiji we need to ensure small minority groups have a say in parliament, and so some Communal constituencies may be necessary. At the same time, small groups sometimes have to compromise vital interests in order to survive. For example, the UPP adopted much of its major partner's policies when it joined with the FLP to form the New People's Coalition. It did not have an independent policy on land and so missed the opportunity to formally address a pressing concern of its migrant Pacific islander communities, some members of whom have been in Fiji for generations but lack rights to land (UPP Manifesto). ${ }^{3}$

\section{A possible way forward}

Fiji has been independent for over 30 years; it has had time to get used to elections and has had experience with two kinds of plurality majority electoral 
systems. Furthermore, it has achieved high literacy rates for both women and men and a highly educated female workforce. Yet despite these positive factors women continue to lag far behind men in positions of responsibility, including participation in national parliament.

Given the experience of other countries and democracies, it is clear that Fiji's plurality majority electoral system will not encourage either rapid increase of women's participation in parliament or the inclusion of minority interests in national decision-making bodies. A review of the Electoral Act, including a review of the electoral system is needed if a more meaningful democracy involving greater representation of women and minority groups is to be achieved. Such a review should seriously consider changing Fiji's elections system to a PR system with fewer communal and more open constituencies. It could also consider the other issues that limit the participation of women and minority groups, including campaign financing, and the issue of making party lists more gender-balanced.

\section{Notes}

1 The author gratefully acknowledges the help of three strong women politicians, Hon. Bernadette Ganilau, Mrs Priscilla Singh and Mrs Fane Vosaniveibuli, who willingly agreed to be interviewed during the preparation of this paper. Any misinterpretations of their parties' policies are entirely those of the author.

2 Reilly, B. \& Reynolds, A. 1999. Electoral Systems and Conflict in Divided Societies, National Academies Press, Washington, DC. Available online at http://www.nap.edu.

3 The issue is, however, being addressed by the women's wing of the party (personal communication, Hon. B. R. Ganilau, 6 July 2006). 